tice and poetry. The novel has also negative points, for example, according to Y. Akhundlu, a reader who does not know the Akhundzadeh's life and period cannot understand the novel or other negative points such as skipping from one event to another, switching to an indefinite text without explanation, etc. But, besides these, the novel is one of the brightest examples of the Azerbaijani historical novel.

\title{
REFERENCES:
}

1. Axundzadə M.F. Әsərləri II cild. Bakı : Şərq-Qərb, 2005. 372 s.

2. Axundzadə M.F. Seçilmiş əsərləri III cild. Bakı : Şərq-Qərb, 2005. $295 \mathrm{~s}$.

3. Hüseynov A.H. Həyatımız və Nəsrimiz. II məqalə. Azərbaycan jurnalı, 11983 N 95. S. 175-190.

4. Elçin. Tənqid və nəsr. Bakı : Günəş nəşriyyatı, 1999. $216 \mathrm{~s}$.

5. "Әdəbiyyat və incəsənət" qəzeti, 19884 noyabr.

6. URL: http://www.edebi.net/index.php/azerbaycan-edebiyat/azerbaycan-cumhuriyeti/5002-cingiz-huseynov-1929.

7. Hüseynov Çingiz. Fətəli fəthi. Bakı : Yazıçı nəşriyyatı, 1986. $709 \mathrm{~s}$.

8. Xatın Güləliyeva. Roman-ədəbi aktual janr kimi. “ipək yolu” qəzeti, № 4 2017. S. 125-133.

9. Qulu Xəlilov Tənqidçilik çətin peşədir: Bakı :Yazıçı 1986. $390 \mathrm{~s}$.

10. Xəlilov P.A. Nəsrimizin Üfüqləri. Bakı : Yazıçı, 1982. $183 \mathrm{s.}$

11. Salamoğlu Təyyar (Cavadov). On yeni Azərbaycan ədəbiyyatı məsələləri. Bakı : BQU nəşriyyatı, 2008. $554 \mathrm{~s}$.

12. Qarayev Y.S. Ulduzların müdrikliyi. Azərbaycan, 1982. No 3, s. 179-189.

13. Axundlu Y.I. Seçilmiş əsərləri, 3 cilddə II cild. Naxçıvan, Әcəmi nəşriyyatı, 2013. $447 \mathrm{~s}$.

\section{MAMMAD SAID ORDUBADI'S CALL FOR NATIONAL INDEPENDENCE AND THE IDEAL OF NATIONAL UNITY IN SATIRICAL FICTION}

\section{ЗАКЛИК МАММАДА САЇДА ОРДУБАДІ ДО НАЦІОНАЛЬНОЇ НЕЗАЛЕЖНОСТІ ТА ІДЕАЛУ НАЦІОНАЛЬНОЇ ЄДНОСТІ У САТИРИЧНІЙ ХУДОЖНІЙ ЛІТЕРАТУРІ}

\author{
Huseynova $P$. \\ orcid.org/0000-0002-0599-7247 \\ PhD Student of the Department of Azerbaijan and World Literature \\ Minghachevir State University
}

\begin{abstract}
Occupying a special place in the history of Azerbaijani literature with large volumes of prose, the founder of the historical novel genre in our national generation, Mammad Said Ordubadi was also known as a talented publicist along with being a poet, playwright and translator, was one of the tireless member of Molla Nasraddin. The great part of the literary heritage of Mammad Said Ordubadi, who was engaged in artistic creativity at the age of 14-15, also consists of feletons. These literary-publicist writings are devoted to important events of the day, have managed not only to catch the pulse of time, but also to keep up with the times. In his works, he touched upon a number of issues that disturbed people, the problem of national unity; has also called for national independence. His publicist heritage, satirical literary prose is one of the golden pages of our literature and press history.

His feuilletons are distinguished by their content and form from the writings of their contemporaries in this genre. It is interesting that these are sometimes in the form of complete prose, sometimes in the alternation form of prose and poetry, sometimes before prose later poetry, sometimes written in full poetry or, after a small introduction of prose, the poetry is written. These prose works often give a small story effect. For example, these feuilletons have at least two copies, their judgments or comparisons are made, and within a small plot, the author pushes the reader to think about a particular issue. Sometimes the name of the feuilleton is in conflict with its content. It also has some kind of ironic effect. In the M.S. Ordubadi's feuilletons in addition to his own signatures, we come across the signatures of other collaborators of "Molla Nasreddin". These signatures are included in the plot as an image, or the author writes his letter formed feuilletons with reference to them. It shows that fourteen thousand seven hundred thirty five signatures per document. Here, satire is condemned by the fact that, despite the fact that the elements of material interest are fighting for their own interests and ignorance of national interest is discredited by satire.
\end{abstract}

Key words: M.S. Ordubadi, national prose, national independence, satirical prose, publicity, feleton.

Займаючи особливе місце в історії азербайджанської літератури, основоположник жанру історичного роману в нашому національному поколінні Маммад Саїд Ордубаді був також відомий як талановитий публіцист, поет, драматург і перекладач. Велика частина літературної спадщини Маммада Саїда Ордубаді, який займався художньою творчістю у віці 14-15 років, також складається з фейлетонів. Ці літературно-публіцистичні твори, присвячені важ- 
ливим подіям сьогодення, зуміли йти в ногу з часом. У своїх роботах він торкнувся низки питань, які хвилювали людей, проблеми національної єдності; закликав до національної незалежності. Його публіцистична спадщина, сатирична літературна проза є однією із золотих сторінок нашої історії літератури та преси.

Його фейлетони відрізняються своїм змістом і фрормою від творів сучасників у цьому жанрі. Цікаво, що вони бувають іноді у формі повної прози, іноді - у чергуванні форми прози та поезії. Ці прозові твори часто дають невеликий сюжетний ефект. Наприклад, фейлетони мають щонайменше дві копії, зроблені їх судження чи порівняння, і в межах невеликого сюжету автор підштовхує читача до роздуму над певним питанням. Іноді назва фейлетону суперечить його змісту. Це також має якийсь іронічний ефект. У роботі М.С. Ордубаді, окрім його власних підписів, ми натрапляємо на підписи інших співробітників «Молли Насреддіна». Ці підписи включаються до сюжету як зображення, або автор пише свій лист, сформований фейлетонами з посиланням на них. 3 нього видно 14735 підписів на документ.

Ключові слова: М.С. Ордубаді, національна проза, національна незалежність, сатирична проза, гласність, фейлетон.

Introduction. Mammad Said Ordubadi, occupies a special place in the history of Azerbaijani literature with a large volume of prose examples and won the title of the founder of a historical novel genre in our national generation, in addition to being a poet, playwright and translator, he was one of the tireless publicist "Molla Nasreddin" also known as a talented one. The great part of the literary heritage of Mammad Said Ordubadi, who is engaged in artistic creativity at the age of 14-15, also consists of felethians. These literary-publicist writings are devoted to important events of the day, not only catching the pulse of time, but also being able to keep up with the times. Since 1906, the first months since the publication of "Molla Nasraddin", M.S. Ordubadi has collaborated with this journal and published his works, including his poems, in his collection. The articles and felonies of the writer in this journal were mainly published under the signature of "Dreamer".

Analysis of recent research and publications. Lachin Mehdiyeva, an employee of the Memory Museum of Mammad Said Ordubadi, writes in a 2010 article published in the "Culture" newspaper "Mammad Said Ordubadi's Publication" about the signatures used by the writer in fictional publicist articles, and the press agencies they published: "Ordubadi's articles have not yet been published in mass, and their exact number has not yet been established. Since 1903, Ordubadi has been operating with different signatures (Muhammad Said, M.S., M.O., Said, Hajiaghazadeh Said, Eastern citizen, and etc.) in the press agencies such as "Shargi-Rus", "Irshad", "Fresh life", "Tuti", "Funny", "Molla Nasreddin", "Progress", "Union", "Simple", "Igbal", "Sadayi-Haqq" and after 1917, he mainly published publicist articles and papers in the "Hummat" newspaper" [3, p. 13].

There is a reason why Mammad Said Ordubadi, the author of large-scale novels and satirical poems, appealed to publicism. Thus, publicity provided the author with more opportunities. Here the author could speak not only the language of the heroes he created, but also of his own language, sometimes revealing the truth, sometimes distorting his thoughts, and sometimes expressing his thoughts on behalf of others. Museyib Mammadov in his monograph "The Power of Publisistic Word", he writes about the opportunities created by publicism: "The author is usually more active in the publicist genre. His every move, sound, breath is heard. It is immediately noticeable to whom and what he is in sympathy, what and whom he hates, and which position he stands. He speaks to security at any time, finds various objects of appeal. Whenever he wants, he can get a different interviewer and start a dialogue with him" [2, p. 135].

Mammad Said Ordubadi also collaborated with "Molla Nasreddin" for nearly 25 years, and this journal helped him grow into a realistic, democratic writer. In his poems and writings, while addressing the painful problems of the time, he urged his people to unite as a national patriotic intellectual and urge them to demand their rights during the difficult political processes, to be ignorant and not to be crushed. Mammad Said Ordubadi in the satirical literary examples from "Molla Nasreddin" journal, following the great modernists Jalil Mammadguluzadeh, Omar Faig Nemanzadeh, promoted the idea of national unity as a concept, responded immediately to the political processes in the Caucasus, Iran, and Turkey, and was able to justify the importance of national awakening in the territories where the Turks lived in Russia and in the whole Turkic world.

His feuilletons are distinguished by their content and form from the writings of their contemporaries in this genre. It is interesting that these are sometimes in the form of complete prose, sometimes in the alternation form of prose and poetry, sometimes before prose later poetry, sometimes written in full poetry or, after a small introduction of prose, the poetry is written. These prose works often give a small story effect. For example, these feuilletons have at least two copies, their judgments or comparisons are made, and within a small plot, the author pushes the reader to think about a particular issue. Sometimes the name of the feuilleton is in conflict with its content. It also has some kind of ironic effect. For example, 
from the contents of author's feuilletons such as "Muslim meetings", "The government Constitution of the Caucasus", "Fathers of the nation" and "Good news" it is clear that, Muslims cannot come together, the fathers of the nation cannot be a father to this nation, the Caucasus government is only remembered for half the empire's work, and the good news is not for us but addressed for others.

Discusssion. In the M.S. Ordubadi's feuilletons in addition to his own signatures, we come across the signatures of other collaborators of "Molla Nasreddin". These signatures are included in the plot as an image, or the author writes his letter formed feuilletons with reference to them. It is one of the literary priori that derive advantage to Ordubadi. For example, the conversation of "Laglagi" and "Hardemkhayal" in the "Conversation" feuilleton and in the "Maktub" feuilleton the letter that is addressed to "Feverish" works for the writer, and he is able to pass on the secret passages to the reader in this conversation and correspondence. It is well known that the "Feverish" is the secret signature of Mashadi Habib Zeynalov. M.S. Ordubadi, enjoying the sense expressed by his signature, begins his feuilleton as follows: "Sir! The heat of your words rises, and when you read, man's tongue is dried up" [4, p. 99].

As we mentioned, despite places is provided with criticism of prejudice, illiteracy, obstacles to cultural development, intellectuals looking at inferiory their language, fight against idle people, busy activities, though it is widely criticized the clergy who deceive the people and seek their own benefit in the Mammad Said Ordubadi's feuilletons, also challenges to national unity, constitutional movement, challenges to national awakening have important place in in these press publications. The issue of national awakening in prose-writers feuilleton, "Letter in the Mother language", published in 1906 in the Molla Nasreddin journal is noted peculiar. With ironic language of the satire, the author pointed to the first number of the journal "Molla Nasreddin" and wrote: "Son of a deceased, you know that when you make waking up a person who sleeps too much, person suddenly becomes mad and maybe frenzied. When you beat the nation in your first number, you hit the guy on the left side of the fleet, he was crazy, he can't be saved now" [4, p. 101].

Apparently, the author wants to show that the work of collaborators is not in vain, that young people are calling for a national awakening, but that the older generation does not accept or understand it, and it attracts people to the criticism of satire. Mammad Said Ordubadi in his 1906 satire "I had a heart attack", published by "Molla Nasraddin", gives the two people a chance to talk about how Muslims cannot pursue free politics and cannot use their national wealth independently. We read feuilleton: "There are many Islamic governments in Africa that have large lands and millions of influences than the Caucasus. He said: Well, what is their office, independent and dependent? I said: they are eating their bread in secret. He said, "How?!!... I saw he will give me a lot of headaches. I want to be quiet, I said, and they are just as comfortable as our Russian Muslims" [4, p. 108]. This dialogue compares the territory inhabited by Muslim and African Caucasian Muslims, which are supposed to be independent but have become victims of Western policy. The result seems to be that they are victims of the same policy. Despite the large number, the author is concerned about their inability to claim their rights due to cultural backwardness. Ordubadi writes in the first paragraph of the poem he added to the feuilleton:

We are in leisure, torment would cry if saw us,

If my grief is visible, it was probably sad.

Who saw for once would cry forever,

As I write the name of Islam, my pen will cry [4, p. 108-109].

In these hemistiches, it is clear that Ordubadi's concern for the Islamic world, that he is crying over the problem of violation of the rights of Muslims by the sophisticated Christendom policy of solidarity. Mammad Said Ordubadi, pointing out that our cultural backwardness and lack of rights are the cause of these issues, 'Letter' published in 1906 he added to the feuilleton: "Dear brother, Dreamer! Thousands of thanks, we live in luxury and leisure in the graciousness of the government, and day by day we blend into the world of progress and prosperity". As an electric fan in the Asian arena, we have been able to illuminate the world-culture of illuminated body-type and humanity [4, p. 110]. The author, in fact, denies that he admits in this article, that he wished for what he really wanted, and the truth was obvious.

The literary article "Nationalist Intelligence" saw that one of the reasons why we pursued such a drastic policy, was mourning and fearing independence, was that our national intellectuals were far from nationalism. In this feuilleton, which pervades the little story, the image exposes itself in its own language. Our clever Russian-speaking intelligentsia has criticized newspapers in our native language, saying, "Russians don't make friends with Muslim newspaper readers". But in the end, he declares the truth: "The young man turned to me and whispered slowly to my ear: "You are going to die, I have no Islamic education" [4, p. 116]. 
Mammad Said Ordubadi also pointed to the importance of establishing national society, alliances and parties for national unity, as did other contemporary, like-minded and allies. In his book feuilleton, "The Muslim Congregation" wrote that, "It is clear that from one hand voice is missing", say the author tries to explain the reasons for the lack of Muslim solidarity. Using satire weapons, he first tries to highlight the importance of a joint gathering for the idea community, as a basis for the discussion: "There has never been a Muslim community invited to a parliament to be ready in time. For example, thirty people are called, fifteen are coming, waiting for those who are not coming, waiting for them, and smashing a few cigarettes. Fifteen men, who had never come before, came and waited for these fifteen men, waiting for them and smashing a cigarette" [4, p. 117].

"What's the reason?" Why aren't Muslims all gathered at the same time when they are invited together?" The author himself answers his own question. But the answer is also very funny and melancholy. The author sees this as the lack of general interest in the calling space, the absence of free plov (National Azeri cook) or at free tea. He writes: "The reason is that despite person has plov in his own home it is not as delicious as in other home. $<\ldots>$ since the creation of the world till today there was no case that a Muslim is invited into a plov feast and he does not come there. No matter how important it is, he will go, hang a hundred plov pots in his house, go, or is sick, or has a sick at home, or it is raining, walk, and touch the world. No matter how far off he is, he will go" [4, p. 118]. What is more alarming is that the author's observations show that the interest in eating and drinking is superior to the national interest.

Mammad Said Ordubadi, in the 1906 edition of the "Molla Nasreddin" journal, "The Caucasusrelated divergence" used sixty-year-old warheads in the early 19th century to control their own use of the war between Russia and Iran. It shows that fourteen thousand seven hundred thirty five signatures per document. Here, satire is condemned by the fact that, despite the fact that the elements of material interest are fighting for their own interests and ignorance of national interest is discredited by satire.

At the same time, Mammad Said Ordubadi, in his article, gives a report by Russian military commander Nikolai Paskevich, who boldly reveals that Russia invaded Azerbaijan from the first person's language, while also respecting Azerbaijani heroes like Yerevan's father Hassan Khan: "Thanks to the khan, the first thing that gives me a lot of difficulty is the Ottoman Kurds, the secular Iranian refugees and the fate of Hassan khan, Iravan's father.
Let the khan be alive, I am not afraid of any of them, and I hope that we shall possess this province for a month" [4, p. 121].

The author's book "Khans of Azerbaijan" published in 1907 in "Molla Nasreddin" also raises the question of the management of Azerbaijan by national personnel. The author begins the article with the question: "How many khans are there in Azerbaijan?" Comparing the records of the German traveler Reigart and the English traveler Becker, Mammad Said Ordubadi points out that 2522 khans were mentioned in the first work and 2323 in the second book. Stating that the difference between the two indicators stems from the fact that Becker did not take into account the khans who lived in the province of Nam, Mammad Said Ordubadi wants to show that there are 190 khans in one province of Azerbaijan, but they are not even worth a khan with 99 sons. Undoubtedly, the word "padshah" (king) is used figuratively in this article. "Khan" is a title here. The author wants to show that in a country with such a rich and educated human potential, the fact that governance is in the hands of other nations must be understood as a tragedy.

Towards the end of the article, we read: "From the office: We heard that a lot of people in Europe were crying after reading this story in Reigart's book. But when we read such news from newspapers or books, we say to ourselves, "Mashallah, Mashallah!" [4, p. 130] Although, in Europe, these statistics are accepted as a source of danger, we have to be content with saying "mashallah, mashallah". As the name of Mammad Said Ordubadi in his book "Millət atalar1" (Fathers of nation") published in 1907 illustrates what the national bourgeoisie should do for the benefit of the people. As we read in the article: "It is well known that in many places the ancestors of nations now have the idea to lead the nation forward and they come together day and night, that they may consult and do something" [4, p. 131]. At first glance, the title of the article fits with beginning perfectly. However, the author regrets that these people do not do anything but express themselves and show their abilities, waste time on empty, meaningless consultation. Although the city of Vladikavkaz was shown as a venue, it was a message to the bourgeoisie of the whole East, but also of Azerbaijan. Thus, Mammad Said Ordubadi ends the article with such final: "We call on the "new life" not to be offended because we speak these ideas in a benevolent way, or our intention is not to betray the people of Vladikavkaz" [4, p. 132].

Mammad Said Ordubadi, who urged people to be vigilant and not to become victims of Tsarist Russia's policy, after talking about a few tricks 
of the traders brings the weapons and ammunition into his article "Ticarət və ekonomi xəbərlər" ("Trade and Economy News") published in 1907. He notes that states and factories producing weapons in this process are interested in creating conflict zones for greater profit, when such conflicts occur on a national basis, they spend much more time and financial on the basis of their longer duration and greater coverage, persuade people that hatred can arise between nations at any time: "Conscious and experienced people come together and hide the rifle and cartridge, and know that there is no respect for the rifle and cartridge, because now there is peace" [4, p. 140].

The author advised not to follow the provocative satanicism: " $<\ldots>$ if a Muslim kills an Armenian or vice-versa, an hour-long Armenian-Muslim conflict will begin. $<\ldots>$ There is nothing easier than that: At least I can find an avid person and give him ten manat or a hundred manats: Armenian, go kill a Muslim, or vice-versa. That is enough. And I know that the fight will start" [4, p. 140-141]. This satirical article also shows that the Armenian-Muslim conflict was not only purpose to keep this region, but also a source of income for the Tsarist Russia government. Mammad Said Ordubadi in a feleton titled "Dərd" (sorrow) published in the journal Molla Nasraddin in 1910 said that it was time to tell the authors secretly: "By God forbid, you have to say your ideas openly, there is no point in hiding them" $[4$, p. 160]. Here we have reviewed the satirical examples and feletons of Mammad Said Ordubadi, published in the magazine Molla Nasreddin from 1906-1910. We were informed that the ideas of national unity and the call for freedom were sometimes secret and sometimes explicit. Although these articles and feletons are unique to those who support Molla Nasraddin, each of these articles clearly identifies the author's own style.

Despite the advocacy of the theologians of the twentieth century in the doctoral dissertation on the theme: "Problems of development of Azerbaijani satire (1920-1980)" of Badirkhan Ahmadov, he describes the absence of favorable conditions for the existence of satire: " $<\ldots>$ As in different times, in the 20 s there were no objective conditions for the development of satire and humor. Obviously, political processes did not allow this. Although many theorists have been concerned with the importance of satire in these years without fear of being called fogy" $[1$, p. 20].

Mammad Said Ordubadi is also known for his satirical content, among the most influential stories written in the 20-30s of the 20th century. Some of these stories are embodied in an allegation against the new government. True, this attitude is often expressed in the language of the negative hero.
But the voice of this attitude can also be regarded as a voice of protest.

For instance, in the story of "Q1rx dənə baqqal" ("Forty grocers"), published in 1928 in the "Yeni yol" newspaper, but not later published and included only in "Selected Works" in 1964, in the background of an interesting plot Russia's colonial policy, its subordination to the will of its people, and their opposition to their wishes and desires are fueled by satire on the example of behavior of tsar officials and flattering national personnel. We read the words of the interpreters in the name of the grocer, who thought they were sent to exile: "Who says you laugh at the church bell? Your profession is to laugh at your chairman's dog. Last week, when the Sheikh prayed to the emperor himself, nor his wife, his daughters, his son or anyone said "Amin" [4, p. 294].

Although the former structure here was subjected to criticism, in fact, at the time the story is written, it tells of simple, innocent people who are being persecuted, arrested, and sent into exile. Their unfair persecution due to laughing at what someone wants to make accepted as value, for not praising what they didn't like is criticized. One of the author's fascinating, satirical stories that at the same time causes a lot of laughter and is also thought-provoking is the "Boşboğazlar məhkəməsi" (Court of chatterbox). The founders of socialism and the ideology of communism K. Marx and F. Engels are criticized here from the name of a chatterbox called Mirza Niyaz, who presents himself as a scientist.

We read in the story "Lately I've been working on Marx and Engels. You know that our group has given me a great task to show that the idea of Bolshevism and socialism is false. $<\ldots>$ I'm writing an important work on completing Engels' work after Marx right now" [4, p. 301].

At first glance, such words as "the idea of Bolshevism and socialism is a false idea" do not appear suspicious in terms of Soviet ideology because of the negative hero's language - one who refuses to pay fatherly debt and deceives women with beautiful words; but when we think carefully we can see that this is a disgraceful effect.

Although the date of writing of the work is not fully known, it is known that it was first published in the Literature Newspaper in 1935. Another satirical story, written by the author on the eve of the thirties, the repression nightmare of the 20th century, also expresses its opposition to the existing structure. In this story, called "Şahqulu bəyin nəvəsi" ("Grandchildren of Shahkulu Bay") the author expresses a textual objection to the kolkhoz structure. The story is based on the image of Mirza Kazim 
Kazimich, who did not get a job because he was a representative of the bay family and grocer Mashadi Hashim trying to be a relative of "bay" through getting married with one of Mirza Kazim's underage teenage girls. The author succeeds in telling the truth in the story of "Şahqulu bəyin nəvəsi" still hiding in the language of negative images. For example, Mashadi Hashim says: "God is the Most High. The world will not always be like this" [4, p. 310]. Or, we hear from Tahmaskulu, an elder resident of the village of Kechigulag: "Kolkhoz is about to begin, so they will not let us to there" [4, p. 313].

It is clear from the contents of the work that the "golchomags" (rich peasants) and the middle class of Kechigulag village apply for entry into kolkhoz after selling the livestock at the advice of Mirza Kazim. The new government, aware of this, also sent them into exile. At the end of the work we read: "The carriage of the family of Mirza Kazim Kazimich, the grandson of Shahgulu bay, was the foremost.
Behind this cart was the "golchomags" of the village of Kechigulag, and in the most behind was the grocer Mirza Kazim and Mashadi Hashim" [4, p. 321].

Conclusion. As you can see, in the work representatives of the old structure - Mirza Kazim, who previously worked as a interpreter under the commissioner, womanizer Mashadi Hashim, who wanted to marry a young girl and become a relative of "bay", rural landowners who did not want to participate in kolkhoz are being criticized. When carefully considered, the author in this story expresses his dissatisfaction with the existing regime, creating an episodic image of innocent exiles of people due to selling their property to not hand over to government.

Note that this story was not published in the author's life. Preserved in the personal fund of Mammad Said Ordubadi and included in the Selected Works only in 1964 on the basis of archival materials of the Republican Manuscript Fund. This, in itself, gives reason to think.

\title{
REFERENCES:
}

1. Ohmədov Bədirxan. Azərbaycan satirasının inkişaf problemləri (1920-1980-ci illər) Azərbaycan ədəbiyyatı ixtisasından filol.e.d. alimlik dərəcəsi almaq üçün təqdim olunmuş dissertasiya. Bakı, 2005, $300 \mathrm{~s}$.

2. Məmmədov Müseyib. Publisistik sözün qüdrəti. Bakı, Yazıçı, 1992. $144 \mathrm{~s}$.

3. Mehdiyeva Laçın. Məmməd Səid Ordubadinin publisistikası, "Mədəniyyət" qəzeti, 5 may 2010-cu il.

4. Ordubadi Məmməd Səid. Әsərləri, Səkkiz cilddə, I cild (şeir, felyeton və hekayələr). Bakı, Azərnəşr, 1964. $447 \mathrm{~s}$.

УДК 82.02

DOI https://doi.org/10.32782/tps2663-4880/2020.13-3.34

\section{THE ROLE OF MUGAM IN DISCOVERING THE SPIRITUAL ATTITUDES OF STUDENTS}

\section{РОЛЬ МУГАМІВ У РОЗКРИТТІ ДУХОВНИХ УСТАНОВОК УЧНІВ}

\author{
Jafarova M., \\ orcid.org/0000-0001-5046-4979 \\ PhD, Department of Musicology \\ Nakhchivan State University
}

Teaching mugams in secondary schools of the Republic of Azerbaijan is carried out both in the learning process, in extracurricular activities, and in out-of-class and out-of-school activities. However, mugams are presented only as aesthetic education in these activities. It should not be forgotten that mugams are not only aesthetics tool but also have high moral qualities for schoolchildren. There are a number of scientific, pedagogical, psychological and methodological directions of teaching mugam to children in the pedagogical process. Mugam singing habits are often formed by the power of imagination. When imaginative small abilities are sustainable, they can become a means of communication and information. Some researchers wrongly limit the performance of mugam with vocal capabilities. The paralling system includes vocalization - the range, the tone, the timbre. Extralinguistic as well as the paralyzing system is an additional opportunity for speech impact, clarity and attractiveness. When we talk about pedagogical basics, it is important to remember that our mugams are a means of education. Because mugams not only enjoy high artistic taste in children, they also nurture them. From these mugams, the Bayati-Shiraz mugam, which draws attention with its fascinating notes, nostalgic feelings, and character, is more likely to evoke the moral qualities of the listener. It is no coincidence that many classifications, folk songs, dances and tunes were created on Bayati Shiraz. Consequently, these mugams have played a special role in 